\title{
Penggunaan TVP dan Aplikasi Pasteurisasi dalam Pembuatan Sosis Sapi Goreng di PT. X
}

\section{The Use of TVP and Application of Pasteurization in Production of Fried Beef Sausage in PT. $X$}

\author{
Akbar Pradana $^{1)^{*}}$, Joko Hermanianto ${ }^{2)}$, Sugiyono ${ }^{2)}$ \\ ${ }^{1)}$ Magister Profesional Teknologi Pangan, Institut Pertanian Bogor, Bogor \\ ${ }^{1)}$ Departemen Ilmu dan Teknologi Pangan, Fakultas Teknologi Pertanian, Institut Pertanian Bogor, Bogor
}

\begin{abstract}
With the price of beef that fluctuates from time to time, Company ' $X$ ' attempted the innovation with analog meat or Textured Vegetable Protein (TVP) to replace some of percentage of meat used in the formula. The objective of this research is to create fried beef sausage formula with TVP to improve the cost and understand the effectiveness of pasteurization for the product to extend the shelf life. This research showed that 2\% of TVP can replace 7\% of meat from the total meat used in the existing formula of fried beef sausage. This research also proved the result from the application of 30 minutes pasteurization for both fried beef sausage formula with TVP and the existing one. Fried beef sausage with pasteurization application can achieve 45 days of shelf life compare to the existing formula without pasteurization application only only 30 days and can reduce $9 \%$ of the cost and decrease the product return from the market due to spoilage from $4 \%$ to $0.5 \%$.
\end{abstract}

Keywords: fried beef sausage, Textured Vegetable Protein (TVP), pasteurization

\begin{abstract}
Abstrak. Dengan harga daging sapi yang fluktuatif dari waktu ke waktu membuat PT. X melakukan inovasi penggunaan daging analog atau Textured Vegetable Protein (TVP) untuk menggantikan sebagian daging sapi. Tujuan dari penelitian ini adalah membuat formulasi TVP yang dapat digunakan pada sosis sapi goreng untuk menstabilkan biaya dan mengetahui efektifitas aplikasi pasteurisasi terhadap produk untuk memperpanjang umur simpan. Penelitian ini menunjukkan bahwa 2\% Textured Vegetable Protein (TVP) dapat menggantikan sebanyak 7\% daging dari total daging yang digunakan pada formula sosis sapi existing. Penelitian ini juga membuktikan hasil aplikasi pasteurisasi selama 30 menit terhadap formula sosis sapi goreng menggunakan TVP maupun sosis sapi goreng existing. Sosis sapi goreng dengan aplikasi pasteurisasi memiliki umur simpan hingga 45 hari sementara formula existing tanpa aplikasi pasteurisasi hanya mampu bertahan hingga 30 hari dan dapat menghemat biaya $9 \%$, dan menurunkan retur barang dari pasar karena penurunan kualitas produk dari $4 \%$ menjadi $0.5 \%$.
\end{abstract}

Kata Kunci: sosis sapi goreng, Textured Vegetable Protein (TVP), pasteurisasi

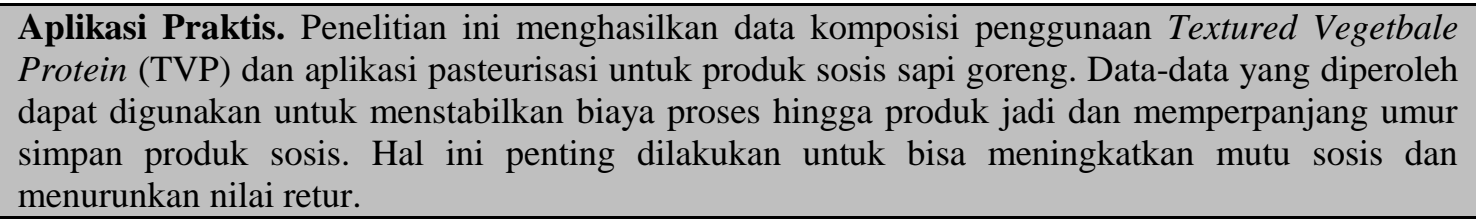

\section{PENDAHULUAN}

Salah satu olahan daging yang mengkontribusi pasar adalah sosis. Sosis merupakan pangan olahan yang terbuat dari daging maupun campuran beberapa daging halus dan dicampur dengan bumbu-bumbu. Umumnya sosis dibuat dari campuran daging ayam atau sapi dengan bahan tambahan lainnya. Sosis daging dikelompokkan menjadi dua, yaitu sosis daging dan sosis daging kombinasi. Sosis daging merupakan sosis yang memiliki kandungan daging minimal sebesar 35\%, sedangkan sosis daging kombinasi memiliki kandungan daging minimal sebesar 20\% (BSN 2015).
PT. X merupakan salah satu industri pengolahan makan dari daging sapi dan daging ayam yang di Indonesia. Salah satu produk hasil olahan daging sapi yang diproduksi PT. X adalah sosis sapi goreng. Dalam proses pembuatan sosis PT. X memenuhi kebutuhan dagingnya dengan cara mengimpor dari Australia dan Selandia Baru. Hal ini karena daging dari luar atau impor memiliki harga lebih murah dibandingkan harga lokal (Ilham 2009; Zainuddin et al. 2015; Istiqomah 2014). Berjalannya waktu harga daging sapi yang fluktuatif di Indonesia akan mempengaruhi biaya produksi dalam pembuatan olahan daging (Harmini et al. 2011; Sutawi 2007). Untuk itu PT. X tetap berpoduksi dan 
mempertahankan biaya, PT. X melakukan inovasi menggunakan Textured Vegetable Protein (TVP) sebagai pengganti sebagian daging.

Pada awalnya produksi daging analog atau TVP dirancang untuk memenuhi pasaran konsumen vegetarian saja, akan tetapi karena telah terjadi perubahan gaya hidup masyarakat, daging tiruan juga dipakai oleh perusahaan pangan untuk penghematan biaya. Daging tiruan yang digunakan pada umumnya produk protein kedelai yang disebut TVP. Penggunaan TVP dapat menghemat daging sapi untuk diolah menjadi produk. Seberapa banyak jumlah TVP yang digunakan tergantung dari rasa dan tekstur yang dapat diterima oleh konsumen. Penggunaan TVP sangat mempengaruhi tekstur khususnya kekenyalan dan rasa (Winarno 2012). Dalam penelitian ini TVP digunakan untuk menggantikan sebagian dari daging sapi. Proses tersebut diaplikasikan ke produk sosis sapi goreng. Sosis sapi goreng merupakan produk olahan daging yang sangat diminati oleh konsumen dan dapat diolah keberbagai menu makanan yang berbasis sosis.

Dengan substitusi daging dengan bahan nabati seperti TVP, Tepung, ISP, dan protein nabati lainnya menyebabkan mutu dan umur simpan sosis menjadi menurun. Kemunduran mutu sosis ditandai dengan adanya air, lendir, hingga bersusu. Proses pasteurisasi dilakukan untuk menghambat kemunduran mutu dari sosis sapi goreng. Pasteurisasi adalah pemanasan dengan suhu tertentu dan waktu tertentu. Pemanasan pada suhu pasteurisasi dimaksud untuk membunuh sebagian bakteri patogenik yang ada dalam olahan pangan dan mempertahankan semaksimal mungkin sifat fisik dan cita rasa (Abubakar et al. 2001). Efektifitas proses pemanasan dan peningkatan daya awet yang dihasilkan pada proses pasteurisasi tergantung pada beberapa karakteristik bahan (Syah 2012). Dalam penelitian ini proses pasteurisasi dilakukan setelah formula sosis sapi goreng yang menggunakan TVP tidak berbeda nyata untuk tekstur, rasa, dan aroma dibandingkan dengan sosis sapi goreng existing.

Berdasarkan hal tersebut, maka penelitian ini dilakukan untuk mengembangkan produk sosis sapi sapi goreng dengan TVP untuk menggantikan sebagian daging sapi sebagai upaya menstabilkan biaya produk dan aplikasi pasteurisasi untuk memperpanjang umur simpan.

\section{BAHAN DAN METODE}

\section{Bahan}

Bahan utama yang digunakan adalah daging sapi dan texturized vegetable protein (TVP) atau daging analog. Bahan lain yang digunakan adalah air es atau es, garam, lemak, sodium tripolifosfat (STPP), bahan pengikat atau bahan pengisi, bumbu-bumbu, selosong sosis dan dikemas plastik vakum.

\section{Tahapan penelitian}

Penelitian ini dilaksanakan di Laboratorium Research and Development PT. X. Pengujian dan pengamatan dilakukan di Labrotarium R\&D PT. X. Penelitian ini dilakukan dalam 2 tahap.

\section{Tahap 1. Penggunaan TVP dalam formulasi sosis sapi goreng}

Penelitian pendahuluan dengan cara melakukan modifikasi formula dengan penggantian sebagian daging sapi dengan TVP hingga menyerupai sosis sapi goreng existing yang di pasarkan oleh PT. X. Penelitian pendahuluan yang sudah menyerupai target existing dilakukan uji sensoris dengan menggunakan uji segitiga di internal PT. X dan eksternal. Uji segitiga (triangle) merupakan uji untuk mendeteksi perbedaan terkecil. Dalam uji segitiga diberikan 3 sampel (2 sampel sama dan 1 sampel berbeda) dan pilih salah 1 dari 3 sampel yang berbeda (Ayustaningwarno 2014). Pada penelitian pendahuluan formula sosis sapi goreng menggunakan Textured Vegetable Protein (TVP) dilakukan uji segitiga dengan panelis terlatih di perusahaan PT. X. Setelah panelis tidak dapat membedakan atau hasil dari uji segitiga tidak berbeda nyata, dilakukan uji lanjutan dengan panelis eksternal (konsumen sosis sapi goreng). Setelah uji segitiga dengan hasil tidak berbeda nyata dilanjutkan ke penelitian tahap 2 .

Tahap 2. Penelitian kedua adalah proses pasteurisasi

Sosis sapi goreng yang dipasteurisasi adalah existing dan menggunakan TVP yang telah diuji sensoris dengan hasil uji segitiga yang tidak berbeda nyata antara existing dan menggunakan TVP. Proses pasteurisasi dilakukan setelah sosis sapi goreng dengan TVP dan existing telah dikemas vakum. Kemudian di pastuerisasi pada suhu $85^{\circ} \mathrm{C}$ dengan 2 waktu yang berbeda yaitu 30 menit dan 45 menit. Setelah pasteurisasi dilakukan penyimpan dengan suhu chilled $\left(0-5^{\circ} \mathrm{C}\right)$ selama 2 bulan atau hingga tidak layak untuk dikonsumsi. Perlakuan penelitian disajikan pada Tabel 1.

\begin{tabular}{cccc}
\multicolumn{3}{l}{ Tabel 1. Perlakuan penelitian } & \\
\hline Perlakuan & $\begin{array}{c}\text { Non } \\
\text { Pasteurisasi }\end{array}$ & $\begin{array}{c}\text { Pasteurisasi } \\
30 \text { Menit }\end{array}$ & $\begin{array}{c}\text { Pasteurisasi } \\
45 \text { Menit }\end{array}$ \\
\hline Existing & & & \\
T1 & & \\
T2 & & & \\
T3 & & \\
T4 & & & \\
\hline
\end{tabular}

Keterangan: Exisitng : Formula existing tanpa pasteurisasi; T1 : Formula existing perlakuan pasteurisasi 30 menit; T2 : Formula existing perlakuan pasteurisasi 45 menit; T3 : Formulasi dengan TVP perlakuan pasteurisasi 30 menit; T4 : Formulasi dengan TVP perlakuan pasteurisasi 45 menit

\section{Uji umur simpan dengan metode konvensional}

Uji umur simpan sosis sapi goreng menggunakan TVP dibandingkan sosis sapi goreng existing. Di analisa di suhu ruang $\left(25-30^{\circ} \mathrm{C}\right)$ dan suhu chiller $\left(0-5^{\circ} \mathrm{C}\right)$. Menurut Koswara (2009), suhu penyimpanan yang baik untuk daging dan olahan daging adalah $0.5-3.3^{\circ} \mathrm{C}$. Suhu pengamatan tersebut adalah suhu yang diaplikasikan di pasar tradisional dan pasar modern. Uji umur simpan diamati hingga produk tidak layak untuk dikonsumsi. Sosis sapi goreng yang tidak layak konsumsi ditandai dengan warna sosis memucat, aroma mengarah ke asam, kemasan loss vacuum, berair, dan berlendir. 
Analisa mikrobiologi merupakan suatu analisa yang dilakukan untuk mengetahui perkembangan mikrobia yang ada pada suatu bahan. Analisa mikrobiologi untuk mengetahui jumlah mikrobia, apakah suatu bahan pangan layak untuk dikonsumsi atau tidak. Dalam penelitian ini mengacu pada BSN 2015 No. SNI 3820:2015 mengenai sosis daging. Batas maximum angka lempeng total sosis daging adalah $1 \times 10^{5} \mathrm{koloni} / \mathrm{g}$.

\section{Analisa proksimat}

Analisis proksimat merupakan suatu analisis yang dilakukan untuk mengetahui komposisi kimia yang ada pada suatu bahan. Analisis proksimat dilakukan untuk mengetahui kandungan gizi secara kasar (crude) yang meliputi kadar air dengan menggunakan metode oven (AOAC 2005), protein dengan menggunakan metode kjeldahl (AOAC 2005), lemak dengan menggunakan metode soxhlet (AOAC 2005), dan karbohidrat menggunakan metode (by different) (AOAC 2005).

\section{Analisa biaya}

Analisa biaya diamati dengan membandingkan biaya produk sosis sapi goreng existing dengan biaya produk sosis sapi goreng menggunakan TVP sebagai pengganti daging. Produk dapat dipasarkan apabila biaya tidak berbeda nyata antara sosis sapi goreng existing vs sosis sapi goreng menggunakan TVP. Analisa biaya selanjutnya adalah membandingkan produk dengan proses pasteurisasi dan tanpa pasteurisasi.

\section{HASIL DAN PEMBAHASAN}

\section{Penggunaan Texturized Vegetable Protein (TVP) dalam formulasi sosis sapi goreng}

Penelitian pendahuluan tahap pertama dilakukan untuk mendapatkan sosis sapi goreng menggunakan TVP yang menyerupai sosis sapi goreng existing. Dalam penelitian pendahuluan dilakukan beberapa kali trial hingga menemukan formula final sosis sapi goreng dengan menggunakan kadar TVP 2\% dari total berat adonan dapat menggantikan daging sebanyak $7 \%$ dari total daging yang digunakan. Formula sosis sapi goreng existing dan sosis sapi goreng menggunakan TVP dapat menggantikan sebagian daging disajikan pada Tabel 2 .

Panel dengan pihak eksternal dengan target konsumen yang pengguna sosis sapi goreng. Hal ini dilakukan untuk mendapatkan data yang akurat sebelum formula ini di implementasikan. Sosis sapi goreng yang dipanel eksternal menggunakan uji segitiga. Pada saat proses panel, panelis melakukan analisa pada sosis sapi goreng dengan TVP vs sapi goreng existing. Panelis diberikan 3 sampel, dimana 2 sampel sama dan 1 sampel berbeda. Panelis harus dapat memilih atau menjawab sampel yang berbeda.

Berdasarkan hasil panel eksternal dengan uji segitiga, hanya 25 panelis yang dapat membedakan sosis sapi goreng menggunakan TVP vs sosis sapi goreng existing dari 100 panelis. Hasil panel eksternal dengan uji segitiga antara sosis sapi goreng TVP dan sosis sapi goreng existing dapat dikatakan tidak berbeda nyata sesuai tabel yang disajikan. Menurut Adawiyah dan Waysima (2009), uji segitiga dapat dikatakan beda nyata apabila dalam 100 panelis yang harus dapat membedakan minimal sebanyak 42 panelis dengan beda nyata terkecil $5 \%$. Hasil panel uji segitiga disajikan pada Tabel 3.

Tabel 2. Formulasi sosis sapi goreng existing dan sosis sapi goreng dengan TVP

\begin{tabular}{lcc}
\hline \multicolumn{1}{c}{ Bahan Baku } & Existing (\%) & TVP (\%) \\
\hline Daging & 21 & 14 \\
Ice & 18 & 18 \\
Texturized Vegetable Protein (TVP): & & \\
Solae response & & 2 \\
Water & 61 & 5 \\
Gel, bumbu-bumbu dan BTP & 100 & 61 \\
Total adonan & & \\
\hline
\end{tabular}

Tabel 3. Hasil panel uji segitiga

\begin{tabular}{|c|c|c|c|c|c|}
\hline \multirow{2}{*}{$\begin{array}{c}\text { No } \\
\text { Panelis }\end{array}$} & \multicolumn{2}{|c|}{ Segitiga } & \multirow{2}{*}{$\begin{array}{c}\Sigma \text { yang bisa } \\
\text { membedakan }\end{array}$} & \multicolumn{2}{|c|}{ Tingkat Beda } \\
\hline & Kode & Existing/TVP & & $\begin{array}{l}\text { Tidak } \\
\text { Beda }\end{array}$ & Beda \\
\hline $1-25$ & 201 & Existing & 7 & 3 & 4 \\
\hline $26-50$ & 531 & Existing & 1 & 1 & \\
\hline $51-75$ & 792 & TVP & 8 & 7 & 1 \\
\hline \multirow[t]{3}{*}{$76-100$} & 531 & TVP & 9 & 3 & 6 \\
\hline & & Total & 25 & 14 & 11 \\
\hline & & & $25 \%$ & $56 \%$ & $44 \%$ \\
\hline
\end{tabular}

\section{Proses pasteurisasi}

Menurut Murdiati et al. (2004), proses pasteurisasi merupakan pemanasan dengan suhu tertentu dan waktu tertentu. Pemanasan pada suhu pasteurisasi untuk membunuh sebagian bakteri patogen yang ada di dalam olahan pangan. Hal tersebut memiliki tujuan utama yaitu untuk memperpanjang umur simpan olahan pangan. Sosis sapi goreng yang melalui proses pasteurisasi dikemas secara vakum. Menurut Khaira et al. (2013), bakteri yang terkandung dalam kemasan non vakum memiliki jumlah koloni lebih tinggi dibandingkan dengan kemasan yang di vakum. Hal ini dimungkinkan karena pada kemasan vakum pertumbuhan bakteri aerob yang pertumbuhannya sangat tergantung pada oksigen. Proses vakum kemasan sangat penting karena apabila kemasan tidak vakum berarti masih ada udara yang tersisa di dalam kemasan sehingga mikroorganisme dapat tumbuh dan makanan menjadi cepat rusak (Santoso 2015).

Pasteurisasi Suhu $85^{\circ} \mathrm{C}$ merupakan suhu pasteurisasi high temperature short time (HTST) (Abidah 2015). Dalam penelitian ini terdapat dua perlakuan proses pasteurisasi, yaitu dengan suhu $85^{\circ} \mathrm{C}$ selama 30 menit dan 45 menit. Dari hasil pasteurisasi dengan suhu $85^{\circ} \mathrm{C}$ selama 30 dan 45 menit secara organoleptik aroma menjadi kuat, tekstur lebih kenyal, dan warna lebih gelap bila dibandingkan dengan sosis sapi goreng existing tanpa perlakuan proses pasteurisasi. Proses pasteurisasi sosis sapi goreng menggunakan TVP maupun existing selama 45 menit memiliki kendala yaitu selongsong sosis sapi goreng pecah sehingga secara penampilan tidak menarik saat dipasarkan. Hyphotesa dalam penelitian ini melihat proses pasteurisasi yang dilakukan dapat memberikan hasil umur simpan yang lebih baik bila dibandingkan dengan tanpa proses pasteurisasi. Dapat dilihat hasil dan pembahasan dibawah ini. 


\section{Angka lempeng total (TPC)}

Cepat lambatnya kerusakan hasil olahan pangan secara mikrobiologi tergantung pada percepatan pertumbuhan mikrobia yang ada terutama bakteri pembusuk. Dalam pertumbuhan atau untuk memenuhi kebutuhan hidupnya, mikrobia memerlukan energi yang diperoleh dari substrat tempat hidupnya. Daging dengan kadar air yang tinggi merupakan substrat yang baik untuk bakteri karena dapat menyediakan senyawa-senyawa yang dapat menjadi sumber nitrogen, karbon dan kebutuhan lainnya. Meskipun demikian, senyawa-senyawa dalam bentuk makromolekul seperti misalnya protein, lipida, dan karbohidrat komplek tidak dapat digunakan langsung oleh bakteri (Hadiwiyoto 1993). Daging merupakan bahan pangan yang sangat beresiko. Perlakuan penyimpanan, proses, pengemasan dan distribusi yang tidak baik akan mengakibatkan resiko tumbuhnya mikroorganisme (Doulgeraki et al. 2012).

Keberadaan mikrobia dalam pengamatan pada sosis sapi goreng dapat digunakan sebagai parameter produk layak untuk di konsumsi atau tidak, karena semakin besar jumlah bakteri maka semakin besar pula aktivitas penguraiannya. Sosis menurut Hui et al. (2001) merupakan salah satu jenis produk olahan daging konsumsi yang biasanya dibumbui atau diberi rasa pedas untuk menghasilkan beberapa rasa yang intensif. Sosis merupakan bahan pangan yang berasal dari daging sehingga produk ini dapat dengan mudah mengalami kerusakan baik secara kimia, fisik dan mikrobiologi. Berdasarkan BSN 2015 mencantumkan standar jumlah total mikroba untuk produk sosis daging maksimal $1.0 \times 10^{5} \mathrm{koloni} / \mathrm{gram}$ atau $5 \log \mathrm{CFU} / \mathrm{g}$.

Berdasarkan penelitian bahwa perubahan jumlah mikroba pada sosis sapi goreng menggunakan TVP dan sosis sapi goreng existing dengan proses pasteurisasi maupun tanpa proses pasteurisasi menunjukkan semua perlakuan mengalami peningkatan dalam pertumbuhan mikroba pada setiap pengamatan selama penyimpanan di suhu $0-5^{\circ} \mathrm{C}$. Hal tersebut karena adanya perombakan atau dekomposisi protein atau senyawa lain yang mengandung nitrogen selama penyimpanan. Semakin tinggi nilai nitrogen yang dihasilkan karena perombakan oleh protein semakin tinggi jumlah mikroba yang hidup. Pertumbuhan jumlah mikrobia (TPC) disajikan pada Gambar 1 .

Berdasarkan pengamatan pada hari ke- 0 , sosis sapi goreng dengan TVP dan existing dengan perlakuan pasteurisasi selama 30 dan 45 menit memiliki beban bakteri $2.3 \log$ CFU/gram, sedangkan sosis sapi goreng existing tanpa pasteurisasi memiliki beban bakteri $3.4 \mathrm{log}$ CFU/gram. Jumlah awal mikroba yang cukup rendah disebabkan oleh adanya proses pasteurisasi dengan suhu $85^{\circ} \mathrm{C}$ selama 30 dan 45 menit, sehingga mikroba pembusuk yang tidak tahan panas mati. Namun pemanasan pada proses pasteurisasi tidak menjamin seluruh mikroba mati, beberapa spesies bakteri gram positif yang relatif tahan terhahap perlakuan fisik kemungkinan masih terdapat pada produk (Fardiaz 1992).

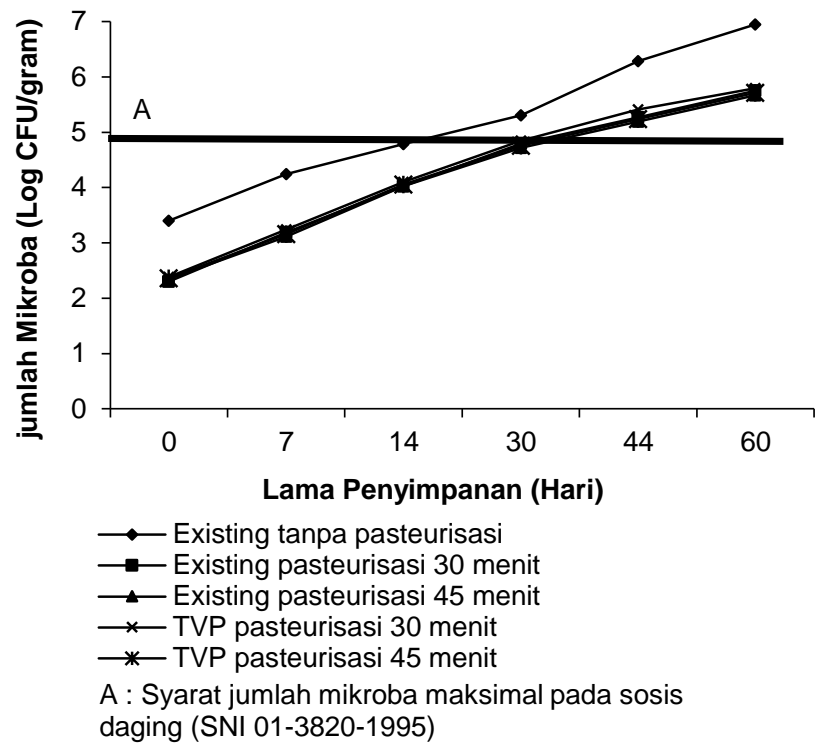

Gambar 1. Pertumbuhan jumlah mikroba (TPC)

Pengamatan hari ke-7 penyimpanan pada suhu chilled menunjukkan peningkatan pertumbuhan mikroba pada sosis sapi goreng tanpa proses pasteurisasi menjadi 4.24 CFU/gram. Dengan meningkatnya mikroba menyebabkan warna pada produk pucat. Menurut Siagian (2002), perubahan warna terjadi karena meningkatnya jumlah mikroba dalam produk. Perubahan warna karena mikroba terjadi di kisaran 3-4 log CFU/gram. Beriringnya waktu pengamatan sosis sapi goreng existing tanpa proses pasteurisasi, pada pengamatan hari ke-15 sosis mulai berair. Dengan lepasnya air menyebabkan mikroba bertumbuh dengan baik. Hal tersebut karena air merupakan substrat yang cocok untuk pertumbuhan mikroba. Dengan meningkatnya pertumbuhan mikroba menyebabkan kemasan menjadi lepas vakum atau loss vacuum. Hal tersebut karena perombakan protein yang semakin tinggi oleh mikroba menyebabkan nilai nitrogen meningkat. Dengan meningkatnya nilai nitrogen menyebabkan terbentuknya gas dalam kemasan.

Proses terjadinya loss vacuum dihari ke-15 diikuti dengan jumlah air yang tinggi dan aroma khas sosis mulai menurun menuju asam dengan jumlah pertumbuhan mikroba $4.78 \log$ CFU/gram. Meningkatnya jumlah air didalam kemasan diikuti dengan meningkatnya pertumbuhan mikroba. Menurut Arwinda (2003), ketika mikroorganisme mulai tumbuh dan menjadi aktif, mereka umumnya menghasilkan air sebagai hasil akhir dari respirasi yang meningkatkan nilai Aw dari lingkungan mereka sehingga mikroorganisme membutuhkan Aw tinggi dapat tumbuh dan merusak makanan yang awalnya dipertimbangkan berada dalam kondisi stabil terhadap gangguan mikroorganisme. Dengan meningkatnya mikroba menyebabkan produk berlendir. Sosis sapi goreng existing tanpa proses pasteurisasi terbentuk lendir pada pengamatan hari ke-22. 
Terbentuknya lendir terjadi oleh bakteri pembentuk kapsul yang jika tumbuh pada medium akan membentuk koloni yang bersifat mukoid, tetapi jika tumbuh pada makanan akan membentuk lendir (Wicaksono 2007). Menurut Fardiaz (1992), lendir merupakan salah satu indikasi adanya mikroba dalam produk, lendir tersebut dapat berfungsi sebagai komponen yang berperan dalam adhesi sel pada permukaan padat. Dengan terbentuknya lendir didalam kemasan, produk sudah mengalami kemunduran mutu dan aroma asam meningkat. Pada pengamatan hari ke-30 sosis sapi goreng existing tanpa proses pasteurisasi produk sudah sangat berlendir, aroma sudah asam, dan tidak layak untuk dikonsumsi dengan jumlah mikroba $5.30 \log$ CFU/gram. Berdasarkan BSN 2015 produk sosis daging batas maksimal untuk di konsumsi adalah $5 \log$ CFU/gram.

Data pengamatan sosis sapi goreng menggunakan TVP maupun existing dengan proses pasteurisasi dengan suhu $85^{\circ} \mathrm{C}$ selama 30 dan 45 menit memiliki kemunduran mutu yang lebih baik bila dibandingkan dengan sosis sapi goreng existing tanpa pasteurisasi. Pertumbuhan mikroba mulai meningkat di hari ke-28 dengan jumlah antara 4.02-4.10 log CFU/gram. Meningkatnya jumlah mikroba ditandai dengan terjadinya perubahan warna yang menjadi pucat. Perubahan warna terjadi karena meningkatnya aktifitas mikroba pada produk. Dengan meningkatnya aktifitas mikroba pada produk menyebabkan produk mulai berair. Produk dalam kemasan mulai berair pada pengamatan hari ke-35. Meningkatnya jumlah air pada kemasan diikuti dengan meningkatnya jumlah mikroba pada kemasan. Ketika mikroorganisme mulai tumbuh dan menjadi aktif, mereka umumnya menghasilkan air sebagai hasil akhir dari respirasi yang meningkatkan nilai Aw dari lingkungan mereka sehingga mikroorganisme membutuhkan Aw tinggi dapat tumbuh dan merusak makanan yang awalnya dipertimbangkan berada dalam kondisi stabil terhadap gangguan mikroorganisme (Arwinda 2003). Pengamatan pada hari ke-35 pertumbuhan jumlah mikroba meningkat menjadi 4.72 -4.76 $\log$ CFU/gram. Dengan meningkatnya air dan pertumbuhan mikroba menyebabkan terjadinya loss vacuum dan aroma khas sosis sudah mulai menurun.

Dengan beriringnya waktu pengamatan dengan pertumbuhan mikroba yang semakin banyak menyebabkan produk berlendir. Produk mulai berlendir terjadi pada pengamatan di hari ke-45. Dengan aroma khas sosis yang menurun mengarah ke asam dan produk berlendir. Dengan terbentuknya lendir menyebabkan produk tidak layak untuk dikonsumsi. Dimana pengamatan sosis sapi goreng existing dan menggunakan TVP dengan proses pasteurisasi pada hari ke-45 jumlah mikrobia sudah mencapai $5.19-5.41 \log$ CFU/gram.

Menurut BSN 2015, batas maksimal sosis daging yang layak untuk di konsumsi adalah 5 log CFU/gram. Berdasarkan data pengamatan yang didapat, sosis sapi goreng existing tanpa pasteurisasi layak dikonsumsi hingga hari ke-30. Untuk sosis sapi goreng menggunakan
TVP maupun existing dengan proses pasteurisasi layak untuk dikonsumsi hingga hari ke-45. Data diatas dapat diartikan, bahwa dengan proses pasteurisasi dapat memperpanjang umur simpan sosis sapi goreng. Proses pasteurisasi dengan suhu $85^{\circ} \mathrm{C}$ selama 30 menit dan 45 menit dapat menghambat pertumbuhan mikroba lebih baik, akan tetapi dengan pasteurisasi selama 45 menit menyebabkan selongsong pada sosis sapi goreng sobek atau pecah. Hal itu menyebabkan tampilan kurang menarik dan tidak layak untuk dipasarkan.

\section{Umur simpan suhu chilled (shelf life)}

Umur simpan merupakan salah satu faktor yang masuk dalam HACCP. Dimana HACCP merupakan suatu sistem pengawasan mutu untuk industri pangan yang dapat menjamin keamanan pangan, yang dapat mencegah bahaya atau resiko yang mungkin timbul dan menetapkan pengawasan tertentu dalam pengendalian mutu pada seluruh rantai bahan yang dapat membahayakan keselamatan manusia. Umur simpan suatu produk adalah batas waktu penyimpanan suatu produk sampai produk tersebut mengalami penurunan kualitas secara sensoris dan fisik yang sudak tidak dapat diterima oleh konsumen (Murdiati et al. 2004). Menurut Busboom dan Field (2003) dalam Vergiyana et al. (2014), Sosis masak hanya dapat bertahan 1 sampai 2 hari pada suhu ruang. Kualitas sosis dapat dipertahankan dengan penyimpanan suhu rendah, pada suhu dingin $\left(0-5^{\circ} \mathrm{C}\right)$ minimal 2 minggu dengan kemasan vakum belum terbuka dan selama 1 minggu dengan kemasan non vakum. Pengujian penyimpanan sosis sapi goreng menggunakan TVP dan sosis sapi goreng existing dengan proses pasteurisasi maupun tanpa pasteurisasi dalam penelitian ini dilakukan dengan uji hedonik dan fisik hingga produk tidak layak konsumsi. Pembahasan perubahan kualitas umur simpan selama menyimpanan di suhu chilled, sebagai berikut dan disajikan pada Tabel 4 .

Pada pengamatan pada suhu chilled sosis sapi goreng existing tanpa pasteurisasi mulai mengalami penurunan diawali hari ke-7 dengan memudarnya warna pada sosis. Beriringnya waktu pengamatan kemunduran mutu kedua pada hari ke-15 ditandai dengan munculnya air pada kemasan. Dengan lepasnya air menyebabkan mikroba bertumbuh dengan baik. Hal tersebut karena air merupakan substrat yang cocok untuk pertumbuhan mikroba. Dengan meningkatnya pertumbuhan mikroba menyebabkan kemasan menjadi lepas vakum atau loss vacuum. Hal tersebut karena perombakan protein yang semakin tinggi oleh mikroba menyebabkan nilai nitrogen meningkat. Dengan meningkatnya nilai nitrogen menyebabkan terbentuknya gas dalam kemasan. Hal tersebut yang menyebabkan kemasan lepas vakum atau loss vacuum. Dengan mikroba yang bertumbuh dengan baik menyebabkan produk menjadi berlendir. Terbentuknya lendir terjadi pada pengamatan pada hari ke 22. Terbentuknya lendir karena produk sudah asam dan tidak layak untuk dikonsumsi. 
Tabel 4. Umur simpan pada suhu chilled

\begin{tabular}{lcccccc}
\hline \multicolumn{1}{c}{ Perlakuan } & \multicolumn{3}{c}{ Suhu Chilled (Hari Ke-) } & & \\
\cline { 2 - 7 } & $\begin{array}{c}\text { Warna Produk } \\
\text { (Pucat) }\end{array}$ & $\begin{array}{c}\text { Aroma } \\
\text { Berkurang }\end{array}$ & Berair & Lendir & $\begin{array}{c}\text { Loss } \\
\text { Vacuum }\end{array}$ & Rasa Asam \\
\hline $\begin{array}{l}\text { Existing tanpa pasteurisasi } \\
\text { Existing pasteurisasi 30 }\end{array}$ & 28 & 15 & 15 & 22 & 15 & 30 \\
menit & 28 & 35 & 35 & 42 & 35 & 45 \\
$\begin{array}{l}\text { Existing pasteurisasi } 45 \\
\text { menit }\end{array}$ & 28 & 35 & 35 & 42 & 35 & 45 \\
TVP pasteurisasi 30 menit & 28 & 35 & 35 & 42 & 35 & 45 \\
TVP pasteurisasi 45 menit & 28 & 35 & 35 & 42 & 35 & 45 \\
\hline
\end{tabular}

Sosis sapi goreng menggunakan TVP dan sosis sapi goreng existing dengan proses pasteurisasi selama 30 dan 45 menit memiliki umur simpan yang lebih baik dibandingkan dengan sosis sapi goreng existing tanpa perlakuan pasteurisasi. Penurunan kualitas dengan proses pasteurisasi dimulai pada hari ke-35 dengan munculnya air pada setiap kemasan perlakuan tersebut. Dengan adanya air didalam kemasan menyebabkan kemasan menjadi loss vacuum. Terjadinya loss vacuum dan partikel-partikel air yang lepas menjadi tempat yang baik untuk mikroba hidup. Hal tersebut yang menyebabkan terbentuknya lendir pada produk. Terbentuknya lendir pada produk terjadi setelah penyimpanan hingga hari ke42. Terbentuknya lendir karena produk sudah mengalami kemunduran mutu dan aroma sosis yang sudah asam. Terbentuknya lendir terjadi oleh bakteri pembentuk kapsul yang jika tumbuh pada medium akan membentuk koloni yang bersifat mukoid, tetapi jika tumbuh pada makanan akan membentuk lendir (Fardiaz, 1992). Menurut Fardiaz (1992), lendir merupakan salah satu indikasi adanya mikroba dalam produk, lendir tersebut dapat berfungsi sebagai komponen yang berperan dalam adhesi sel pada permukaan padat.

\section{Umur simpan suhu ruang}

Pengamatan umur simpan suhu ruang dilakukan karena pemasaran untuk sosis sapi goreng hingga ke pasar tradisional. Pemasaran untuk sosis sapi goreng di pasar tradisional tidak kalah besarnya dengan pemasaran di supermarket. Dalam pasar tradisional produk sosis sapi goreng dipasarkan secara ekstrim, semua produk olahan daging beku hanya diletakan saja dimeja atau lapaknya tanpa pendingin atau tambahan es. Menurut Jay (1978) dalam Suradi (2012), semakin lama penyimpanan produk rantai dingin pada suhu ruang akan semakin banyak basa yang dihasilkan akibat semakin meningkatnya mikroorganisme yang pada akhirnya mengakibatkan terjadinya pembusukan. Proses pembusukan akan diikuti dengan peningkatan $\mathrm{pH}$ dan keadaan ini akan diikuti pula dengan peningkatan bakteri. Dalam penelitian umur simpan pada suhu ruang implementasinya sama seperti di pasar tradisional. Produk disimpan pada ruangan terbuka dengan suhu antara $25-30^{\circ} \mathrm{C}$. Pembahasan perubahan kualitas umur simpan selama menyimpanan, sebagai berikut dan disajikan pada Tabel 5.

Pengamatan umur simpan pada suhu ruang sosis sapi goreng menggunakan TVP dan sosis sapi goreng existing dengan proses pasteurisasi lebih baik dibanding sosis sapi goreng existing tanpa perlakuan pasteurisasi. Dengan proses pasteurisasi selama 30 dan 45 menit mulai mengalami penurunan pada jam ke-28. Penurunan ditandai dengan terjadinya penurunan warna atau memudar. Lalu dilanjuti dengan terjadinya loss vacuum pada jam ke-28 pada setiap kemasan. Terjadinya loss vacuum karena meningkatnya jumlah air dan lendir, dimana air dan lendir merupakan substrat yang baik untuk pertumbuhan mikroba. Dengan pertumbuhan mikroba yang baik aroma menjadi asam. Sehingga sosis sapi goreng menggunakan TVP dan sosis sapi goreng existing setelah diatas jam ke-34 sudah tidak layak untuk dikonsumsi. Sedangkan untuk sosis sapi goreng existing tanpa pasteurisasi, penurunan kualitas dapat dikatakan lebih cepat bila dibandingkan dengan sosis sapi goreng dengan perlakuan pasteurisasi. Hal tersebut dapat dilihat dengan memudarnya warna pada jam ke-24 dan loss vacuum. Dengan meningkatnya jumlah bakteri berjalan lurus dengan meningkatnya air dan aroma sosis mengarah ke asam. Dilanjuti dengan timbulnya lendir yang membuat produk tidak layak untuk dikonsumsi pada jam ke30.

Tabel 5. Umur simpan pada suhu ruang

\begin{tabular}{lccccc}
\hline Perlakuan & \multicolumn{5}{c}{ Suhu Chilled (Hari Ke-) } \\
\cline { 2 - 6 } & $\begin{array}{c}\text { Warna } \\
\text { Produk } \\
\text { (Gelap) }\end{array}$ & $\begin{array}{c}\text { Aroma } \\
\text { Berkurang }\end{array}$ & Lendir & $\begin{array}{c}\text { Loss } \\
\text { Vacuum }\end{array}$ & $\begin{array}{c}\text { Rasa } \\
\text { Asam }\end{array}$ \\
\hline $\begin{array}{l}\text { Existing } \\
\text { tanpa } \\
\text { pasteurisasi } \\
\text { Existing } \\
\text { pasteurisasi }\end{array}$ & 24 & 30 & 30 & 24 & 30 \\
$\begin{array}{l}30 \text { menit } \\
\text { Existing } \\
\text { pasteurisasi } \\
45 \text { menit }\end{array}$ & 28 & 34 & 34 & 28 & 34 \\
$\begin{array}{l}\text { TVP } \\
\text { pasteurisasi } \\
30 \text { menit }\end{array}$ & 28 & 34 & 34 & 28 & 34 \\
$\begin{array}{l}\text { TVP } \\
\text { pasteurisasi } \\
45 \text { menit }\end{array}$ & 28 & 34 & 34 & 28 & 34 \\
\hline
\end{tabular}

\section{Analisa proksimat}

Analisa proksimat dilakukan untuk memenuhi standar yang telah ditetapkan oleh Rancangan Standar Nasional Indonesia (SNI) 3820:2015. Standar Nasional Indonesia tersebut menetapkan untuk sosis daging diantaranya air maksimum $67 \%$, lemak maksimum $25 \%$, karbohidrat maksimum 8\%, dan protein minimum $13 \%$. Hasil analisa proksimat sosis sapi goreng existing dan TVP, sebagai berikut dan disajikan pada Tabel 6 .

Analisa proksimat yang dilakukan pada sosis sapi goreng existing dan sosis sapi goreng menggunakan TVP dengan proses pasterurisasi selama 30 dan 45 menit meliputi kadar air, kadar protein, kadar lemak, dan kadar karbohidrat menurut AOAC (2005), mengatakan hasil 
analisa proksimat sosis sapi goreng menggunakan TVP dan sosis sapi goreng existing dengan proses pasteurisasi selama 30 dan 45 menit dan sosis sapi goreng existing tanpa pasteurisasi kandungan proksimat sesuai dengan yang ditetapkan oleh BSN 2015 No SNI 3820:2015. Dimana setiap analisa protein $12.8-13 \%$, lemak $10-11 \%$, air $53-58 \%$, dan karbohidrat $16-18 \%$ untuk semua perlakuan sosis sapi goreng menggunakan TVP dan sosis goreng existing dengan proses pasteurisasi maupun sosis sapi goreng existing tanpa pasteurisasi.

Tabel 6. Hasil analisa proksimat pada sosis sapi goreng

\begin{tabular}{|c|c|c|c|c|}
\hline Perlakuan & $\begin{array}{c}\text { Lemak } \\
(\%)\end{array}$ & $\begin{array}{l}\text { Protein } \\
(\%)\end{array}$ & $\begin{array}{l}\text { Air } \\
(\%)\end{array}$ & $\begin{array}{c}\text { Karbohidrat } \\
(\%)\end{array}$ \\
\hline $\begin{array}{l}\text { Existing tanpa } \\
\text { pasteurisasi }\end{array}$ & 10.36 & 12.90 & 57.56 & 16.38 \\
\hline $\begin{array}{l}\text { Existing } \\
\text { pasteurisasi } 30 \\
\text { menit }\end{array}$ & 10.52 & 12.68 & 55.13 & 19.01 \\
\hline $\begin{array}{l}\text { Existing } \\
\text { pasteurisasi } 45 \\
\text { menit }\end{array}$ & 10.59 & 12.57 & 58.61 & 15.44 \\
\hline $\begin{array}{l}\text { TVP pasteurisasi } \\
30 \text { menit }\end{array}$ & 10.98 & 12.39 & 57.21 & 15.93 \\
\hline $\begin{array}{l}\text { TVP pasteurisasi } \\
45 \text { menit }\end{array}$ & 10.26 & 12.39 & 53.09 & 20.72 \\
\hline
\end{tabular}

Pada penelitian ini kadar kabohidrat melebihi yang ditentukan oleh SNI 3820:2015. Hal tersebut karena sosis yang diproduksi kadar daging tidak lebih dari $35 \%$. Untuk menggantikan daging produsen menggunakan TVP dan tepung yang lebih banyak, sehingga setelah dianalisa kadar karbohidrat yang terkandung akan tinggi. Hal ini menyesuiakan biaya untuk menghasilkan produk yang baik sesuai regulasi dan harga yang sesuai juga untuk daya beli konsumen.

\section{Analisa biaya}

Dalam penelitian ini tujuan penggunaan TVP adalah untuk menstabilkan biaya produksi sosis sapi goreng karena harga daging sapi yang fluktuatif. Poin tambahan penggunaan TVP untuk menggantikan sebagian daging dapat menurukan biaya. Hal ini karena harga per kg TVP lebih murah dibandingkan harga per $\mathrm{kg}$ daging sapi. Penggunaan TVP sebagai pengganti sebagian daging harus memiliki tekstur, aroma, dan rasa yang sama seperti sosis sapi goreng existing. Perhitungan biaya sosis sapi goreng disajikan pada di Tabel 7.

Dari data sosis sapi goreng dengan menggunakan TVP sebagai pengganti sebagian daging dapat meng- hemat biaya sebanyak $8 \%$ untuk 180 gr, $9 \%$ untuk 360 gr dan $9 \%$ untuk 720 gr. Sosis sapi goreng existing dengan proses pasteurisasi ada penambahan biaya sebesar $2 \%$ untuk $180 \mathrm{gr}, 3 \%$ untuk $360 \mathrm{gr}$, dan 3\% untuk $720 \mathrm{gr}$. Hal tersebut terjadi karena untuk proses pasteurisasi ada biaya produksi yang harus dikeluarkan sebesar Rp. 500,- per kilogram. Sosis sapi goreng menggunakan TVP dan sosis sapi goreng existing dengan proses pasteurisasi dapat menekan biaya secara keseluruhan. Hal tersebut ditunjang dengan hasil analisa umur simpan yang lebih lama dibandingkan dengan sosis sapi goreng existing tanpa perlakuan, sehingga dapat mengurangi return atau retur. Dengan tidak adanya return atau retur perusahaan tidak ada pengeluaran tambahan biaya untuk penarikan dan pemusnahan.

Sosis sapi goreng existing dengan proses pasteurisasi walaupun adanya penambahan biaya proses $2 \%$ untuk 180 gr dan $3 \%$ untuk 360 gr dan 720 gr secara umur simpan lebih baik dibandingkan dengan sosis sapi goreng existing tanpa pasteurisasi. Tambahan biaya tersebut tidak berpengaruh karena dengan umur simpan yang lebih baik dapat menurukan angka return. Dimana sosis sapi goreng existing tanpa pasteurisasi nilai return sebesar $4 \%$. Sosis sapi goreng existing dengan pasteurisasi dapat menekan return menjadi $0.5 \%$, dengan begitu perusahaan dapat menghemat biaya.

\section{KESIMPULAN}

Sosis sapi goreng menggunakan TVP didapat setelah beberapa kali percobaan, setelah melalui panel secara internal di PT. X dan eksternal dengan hasil panel tidak berbeda nyata antara sosis sapi goreng menggunakan TVP dengan sosis sapi goreng existing. TVP $2 \%$ dapat menggantikan $7 \%$ daging yang digunakan. Umur simpan sosis sapi goreng menggunakan TVP dan sosis sapi goreng existing dengan proses pasteurisasi selama 30 menit merupakan perlakuan yang terbaik dibandingkan dengan semua perlakuan. Sosis sapi goreng dengan proses pasteurisasi umur simpan dapat bertahan hingga hari ke-44 pada suhu chilled dan jam ke-34 pada suhu ruang, sedangkan sosis sapi goreng tanpa pasteurisasi umur simpan bertahan hingga hari ke-30 pada suhu chilled dan jam ke-30 pada suhu ruang. Sosis sapi goreng dengan pasteurisasi selama 45 menit tidak disarankan, karena selongsong sosis menjadi sobek atau pecah.

Tabel 7. Perhitungan biaya sosis sapi goreng existing dan TVP

\begin{tabular}{|c|c|c|c|c|c|c|c|c|c|}
\hline \multirow{2}{*}{ Description } & \multicolumn{3}{|c|}{ Exisiting } & \multicolumn{3}{|c|}{ Exisiting Pasteurisasi 30 menit } & \multicolumn{3}{|c|}{ TVP Pasteurisasi 30 menit } \\
\hline & $180 \mathrm{gr}$ & $360 \mathrm{gr}$ & $720 \mathrm{gr}$ & $180 \mathrm{gr}$ & $360 \mathrm{gr}$ & $720 \mathrm{gr}$ & $180 \mathrm{gr}$ & $360 \mathrm{gr}$ & $720 \mathrm{gr}$ \\
\hline \multicolumn{10}{|l|}{ Direct Material: } \\
\hline - Frank meats & $2.235,94$ & $4.471,87$ & $8.943,75$ & $2.235,94$ & $4.471,87$ & $8.943,75$ & $1.823,01$ & $3.646,02$ & $7.292,04$ \\
\hline - Casing & 376,10 & 752,19 & $1.504,38$ & 376,10 & 752,19 & $1.504,38$ & 376,10 & 752,19 & $1.504,38$ \\
\hline - Packaging & 498,47 & 397,47 & 543,82 & 498,47 & 397,47 & 543,82 & 498,47 & 397,47 & 543,82 \\
\hline - Pasterurized & & & & 90,00 & 180,00 & 360,00 & 90,00 & 180,00 & 360,00 \\
\hline Direct labour & 96,71 & 193,41 & 386,82 & 96,71 & 193,41 & 386,82 & 96,71 & 193,41 & 386,82 \\
\hline Variable $\mathrm{OH}$ & 121,57 & 243,14 & 486,29 & 121,57 & 243,14 & 486,29 & 121,57 & 243,14 & 486,29 \\
\hline Fixed $\mathrm{OH}$ & 58,02 & 116,05 & 232,09 & 58,02 & 116,05 & 232,09 & 58,02 & 116,05 & 232,09 \\
\hline Distr cost & 254,40 & 508,80 & $1.017,60$ & 254,40 & 508,80 & $1.017,60$ & 254,40 & 508,80 & $1.017,60$ \\
\hline Loss on def goods & 173,71 & 347,41 & 694,83 & 173,71 & 347,41 & 694,83 & 173,71 & 347,41 & 694,83 \\
\hline Total & $3.814,92$ & $7.030,34$ & $13.809,58$ & $3.904,92$ & $7.210,34$ & $14.169,58$ & $3.491,99$ & $6.384,49$ & $12.517,87$ \\
\hline Saving & & & & $-2 \%$ & $-3 \%$ & $-3 \%$ & $8 \%$ & $9 \%$ & $9 \%$ \\
\hline
\end{tabular}


Dengan pecahnya selongsong membuat tampilan sosis sapi goreng tidak menarik. Penggunaan TVP sebagai pengganti sebagian daging pada sosis sapi goreng dan proses pasteurisasi dapat menghemat biaya produksi sebesar 9\%. Proses pasteurisasi pada sosis sapi goreng existing walaupun ada penambahan biaya, akan tetapi umur simpan lebih baik dari pada sosis sapi goreng existing tanpa pasterurisasi. Proses ini bermanfaat karena dapat menurunkan return menjadi $0.5 \%$ yang sebelumnya $4 \%$.

\section{DAFTAR PUSTAKA}

Abidah NY. 2015. Kajian Proses Pasteurisasi Jelly Drink Cincau Hijau-Rosela dalam Kaleng untuk Menghasilkan Daya Antioksidan Optimum. [Skripsi]. IPB. Bogor.

Abubakar, Triyantini, Sunarlim R, Setiyanto H, Nurjanah. 2001. Effect of temperature and time of pasteurization on the milk quality during storage. $\mathrm{J}$ Ilmu Ternak Veteriner 6(1): 45-50.

Adawiyah DR, Waysima. 2009. Evaluasi Sensori Panduan Praktikum. Departemen Ilmu dan Teknologi Pangan. Fakultas Teknologi Pangan. IPB. Bogor.

[AOAC] Association of Official Analytical Chemyst. 2005. Official Method of Analysis of The Association of Official Analytical of Chemist. Arlington, Virginia, USA: Association of Official Analytical Chemist, Inc.

Arwinda. 2003. Perubahan Kualitas Sosis Ikan Lele Dumbo Sebelum dan Sesudah Penyimpanan (Kajian Suhu dan Waktu Pemasakan). Institut Pertanian Bogor. Bogor.

Ayustaningwarno F. 2014. Teknologi Pangan; Teori Praktis dan Aplikasi. Graha Ilmu. Yogyakarta.

[BSN] Badan Standarisasi Nasional. 2015. Standar Nasional Indonesia (SNI) Nomor 3820: 2015 tentang Sosis Daging. Jakarta (ID): BSN.

Busboom JR, Field RA. 2003. Homemade Meat, Poultry and Game Sausage. Washington State University. Washington.

Doulgeraki AI, Ercolini D, Villani F, Nychas G. 2012. Spoilage microbiota associated to the storage of raw meat in different condition. I J Food Microb 157: 130-141. DOI: 10.1016/j.ijfoodmicro.2012.05.020.

Fardiaz S. 1992. Penuntun Praktek Mikrobiologi Pangan. IPB Press, Bogor.

Hadiwiyoto S. 1993. Teknologi Hasil Perikanan. Jilid 1. Liberty. Yogyakarta.
Harmini, Asmarantaka RW, Atmakusuma Y. 2011. Model dinamis sistem ketersediaan daging sapi nasional. J Ekonomi Pembangunan 12(1): 130-148. DOI: $10.23917 /$ jep.v12i1.211.

Hui YH, Nip WK, Rogers RW, Young OA. 2001. Meat Science and Applications. Marcel Dekker, Inc. New York.

Ilham N. 2009. Kelangkaan produksi daging: indikasi dan implikasi kebijakannya. Analisis Kebijakan Pertanian 7(1): 43-63.

Istiqomah NS. 2014. Kerjasama Australia-Indonesia dalam Bidang Ekspor Impor Daging Sapi. [Skripsi]. Fakultas Ilmu Sosial dan Ilmu Politik, Universitas Hasanuddin.

Jay JM. 1978. Modern Food Microbiology, 2d Ed. Wayne State University, D. Van Nastrand Co, New York.

Khaira W, Leni H, Effendi S. 2013. Pendugaan Umur Simpan Daging Ayam Asap pada Suhu Penyimpanan Berbeda dengan Metode Arrhenius. [Skripsi]. Penelitian Fakultas Teknik Universitas Pasundan, Bandung.

Koswara S. 2009. Pengolahan pangan dengan suhu rendah. ebookpangan.com.

Murdiati TB, Priadi A, Rachmawati S, Yuningsih. 2004. Pasteurised milk and implementation of HACCP (Hazard Analysis Critical Control Point). JITV 9(3): 172-180.

Santoso SP. 2015. Proses Pengendalian dan Pengawasan Mutu Sosis selama Proses Freezing dengan Menggunakan IQF (Individual Quick Frozen) di PT. Charoen Pokphand Indonesia. Laporan Kerja Prakter. Universitas Katolik Soegijapranata. Semarang.

Siagian A. 2002. Mikroba Patogen Pada Makanan dan Sumber Pencemarannya. Fakultas Kesehatan Masyarakat. USU. Sumatera Utara.

Suradi K. 2012. Pengaruh lama penyimpanan pada suhu ruang terhadap perubahan nilai $\mathrm{pH}, \mathrm{TVB}$, dan total bakteri daging kerbau. J Ilmu Ternak Unpad 12(2): 9-12.

Sutawi. 2007. Kapita Selekta Peternakan. Malang: UMM Press.

Syah D. 2012. Pengantar Teknologi Pangan. Bogor (ID): IPB Press.

Vergiyana N, Rusman, Supadmo. 2014. Karakteristik mikroba dan kimia sosis ayam dengan penambahan khitosan dan angkak yang disimpan pada refrigerator. Bul Peternakan 38(3): 197-204. DOI: 10.21059/buletinpeternak.v38i3.5256. 
Wicaksono DA. 2007. Pengaruh Metode Aplikasi Kitosan, Tanin, Natrium Metabisulfit dan Mix Pengawet terhadap Umur Simpan Bakso Sapi Pada Suhu Ruang. [Skripsi]. Fakultas Teknologi Pertanian. Institut Pertanian Bogor. Bogor.

Winarno FG. 2012. Inovasi Daging Analog. VII (8) Food Review Indonesia. Bogor.
Zainuddin A, Asmarantaka RW, Harianto. 2015. Integrasi harga daging sapi di pasar domestik dan international. Bul Ilmiah Litbang Perdagangan 9(2): 109-128. DOI: 10.30908/bilp.v9i2.4.

JMP-11-18-005-Naskah diterima untuk ditelaah pada 22 November 2018. Revisi makalah disetujui untuk dipublikasi pada 28 Oktober 2019. Versi Online: http://journal.ipb.ac.id/index.php/jmpi 